\title{
Intravenous Cloxacillin Induced Agranulocytosis in a Haemodialysis
} Patient

\section{Wong KW*}

Nephrology Unit, Department of Medicine, Queen Elizabeth Hospital, Kota Kinabalu, Sabah, Malaysia

\begin{abstract}
Cloxacillin is a commonly used antibiotic to cover suspected Gram-positive infection and methicillin sensitive Staphylococcus aureus, especially in catheter-related infection. A case of severe agranulocytosis induced by prolonged high dose intravenous cloxacillin is reported here. Changing the antibiotic here led to rapid resolution of the potentially fatal situation caused by this antibiotic. Monitoring of blood count and high index of suspicions are important.
\end{abstract}

Keywords: Cloxacillin; Agranulocytosis; Infective endocarditis; Haemodialysis

\section{Introduction}

Cloxacillin is a common antibiotic prescribed for suspected Grampositive infection and confirmed methicillin sensitive Staphylococcus aureus (MSSA) infection. We report a case of cloxacilin induced agranulocytosis in a haemodialysis patient, initially presented as catheter-related infection (CRI), complicated by infective endocarditis.

\section{Case Report}

Madam H is 60 year-old lady, with a history of hypertension for over 20 years duration. She was diagnosed to have advanced chronic kidney disease (CKD) in early 2011, and a left radio-cephalic fistula (RCF) was fashioned in preparation for her haemodialysis. She was eventually initiated on haemodialysis using the fistula since March 2012. Unfortunately, the fistula was thrombosed after 3 weeks of use, and she needed a temporary right-sided internal jugular double lumen catheter insertion to continue her dialysis. The catheter was then converted to a tunnel catheter on $3^{\text {rd }}$ July 2012. She developed high grade fever the next day, and she was then treated as CRI with intravenous (IV) cloxacillin $1 \mathrm{~g}$ qid, and IV ceftriazone $1 \mathrm{~g}$ od. On examination there was a pansystolic mumur over the left sternal edge. The blood culture done on $4^{\text {th }}$ July 2012 grew Staphylococcus aureus, sensitive to cloxacillin. An echocardiography done on $8^{\text {th }}$ July 2012 showed one small organized vegetation attached to the left coronary cusp of aortic valve, associated with mild aortic regurgitation. It was then treated as infective endocarditis, and her IV cloxacillin was increased to $2 \mathrm{~g}$ every four hour, and her IV ceftriazone was stopped. The plan was to continue the IV cloxacillin at that dose for at least four weeks. Her concomitant medications were: nifedipine $15 \mathrm{mg}$ tds, calcitriol $0.25 \mathrm{mcg}$ bd, valsartan $80 \mathrm{mg}$ od, calcium carbonate $500 \mathrm{mg}$ tds, metoprolol $50 \mathrm{mg}$ bd.

After two weeks of high dose IV cloxacillin, on $23^{\text {th }}$ July 2012, she developed high grade fever, and it was noted that her white blood cell count (WBC) was $0.72\left(\mathrm{x} 10^{3}\right)$, her haemoglobin $(\mathrm{Hb})$ was $9.04 \mathrm{~g} / \mathrm{dL}$, and platelet count of 358 . She was treated as neutropenic sepsis, and IV cloxacillin was stopped, and replaced by IV meropenam and IV gentamicin. She was otherwise comfortable, showing no signs of sepsis beside the high grade fever. Her vital signs (blood pressure and pulse were within normal ranges). Her serial counts were as below in Table 1.

A peripheral blood film showed reduced haemoglobin, white blood cells were of leucopenia with neutropenia, no blast seen, and adequate platelet. There was no eosinophilia. As her TWBC was improving after stopping the cloxacillin, in view of her Staphylococcal infective endocarditis, it was decided to stop the meropenam and gentamicin, and replaced with IV vancomycin on $31^{\text {st }}$ July 2012. The frequency of the IV vancomycin was adjusted according the monitored vancomycin level (keeping the level between 15-20 mg/L).

Repeated blood cultures on $27^{\text {th }}$ July were negative. A repeated Echocardiography on $7^{\text {th }}$ August showed the presence of the same vegetation (no increase in size, no worsening aortic regurgitation, no aortic root abscess). Her CRP was coming down, and there was no further plan from our cardiology such as surgical intervention. She was given a total of four weeks of IV vancomycin (last dose was given on $22^{\text {nd }}$ August 2012). She remained well a year later.

\section{Discussion}

This case demonstrated the potentially fatal side effect of a commonly used antibiotic we use for catheter related sepsis and infective endocarditis. Infective endocarditis is one of the serious complications from an indwelling venous catheter. In some patients on haemodialysis, a double-lumen catheter is important as a vascular access while awaiting a permanent placement of a native fistula. In a developing country with limited resources and necessary personnel (vascular access surgeons), the fashioning of a fistula may be delayed. Thus some patient may need the catheter for a longer than desired period. This increases the probability of a complication such as infection and infective endocarditis. In our centre, IV cloxacillin and ceftazidime or ceftriazone are used as first line antibiotics while awaiting the culture results.

A few antibiotics were known to cause agranulocytosis, such as trimethoprim-sulfamethoxazole, ceftazidime, cloxacillin, clindamycin, gentamycin, and chloramphenicol [1]. Although our patient was given both the IV ceftriazone and IV cloxacillin, it is unlikely that the cause is due to ceftriazone as it was stopped within a few days of its initiation. A few risk factors were also studied and noted to be associated with IV cloxacillin such as serious infections (osteomyelitis, infective endocarditis), prolonged course of IV cloxacillin, with daily dose of 8-12 g [2]. In fact, it was suggested that a total dose of $>150 \mathrm{~g}$ was associated with the development of neutropenia. The average duration

${ }^{*}$ Corresponding author: Wong KW, Nephrology Unit, Department of Medicine, Queen Elizabeth Hospital, Kota Kinabalu, Sabah, Malaysia, Tel: 60138302112, E-mail: drwongkohwei@gmail.com

Received April 25, 2014; Accepted May 30, 2014; Published June 15, 2014

Citation: Wong KW (2014) Intravenous Cloxacillin Induced Agranulocytosis in a Haemodialysis Patient. Gen Med (Los Angel) 2: 142. doi: 10.4172/23275146.1000142

Copyright: ( 2014 Wong KW. This is an open-access article distributed under the terms of the Creative Commons Attribution License, which permits unrestricted use, distribution, and reproduction in any medium, provided the original author and source are credited. 
Citation: Wong KW (2014) Intravenous Cloxacillin Induced Agranulocytosis in a Haemodialysis Patient. Gen Med (Los Angel) 2: 142. doi: 10.4172/2327-5146.1000142

Page 2 of 2

\begin{tabular}{|c|c|c|c|c|c|c|c|c|c|c|c|c|}
\hline & $\begin{array}{l}8 \text { July } \\
2012\end{array}$ & $\begin{array}{l}25 \text { July } \\
2012\end{array}$ & $\begin{array}{c}26 \text { July } \\
2012\end{array}$ & $\begin{array}{l}28 \text { July } \\
2012\end{array}$ & $\begin{array}{l}29 \text { July } \\
2012\end{array}$ & $\begin{array}{l}30 \text { July } \\
2012\end{array}$ & $\begin{array}{c}31 \text { July } \\
2012\end{array}$ & $\begin{array}{l}2 \text { August } \\
2012\end{array}$ & $\begin{array}{l}3 \text { August } \\
2012\end{array}$ & $\begin{array}{l}5 \text { August } \\
2012\end{array}$ & $\begin{array}{l}7 \text { August } \\
2012\end{array}$ & $\begin{array}{c}13 \text { August } \\
2012\end{array}$ \\
\hline $\begin{array}{l}\text { Total white blood cell } \\
\text { (TWB C, } \times 10^{3} \text { ) }\end{array}$ & $\begin{array}{c}6.2 \\
9\end{array}$ & $\begin{array}{l}0.6 \\
6\end{array}$ & $\begin{array}{c}1.0 \\
0\end{array}$ & $\begin{array}{c}1.3 \\
0\end{array}$ & $\begin{array}{c}1.7 \\
6\end{array}$ & $\begin{array}{c}2.0 \\
0\end{array}$ & $\begin{array}{c}2.7 \\
6\end{array}$ & 3.71 & 5.06 & 7.42 & 6.77 & 7.97 \\
\hline $\begin{array}{l}\text { Neutro phil count } \\
\left(\mathrm{x} 10^{3}\right)\end{array}$ & $\begin{array}{c}3.8 \\
4\end{array}$ & $\begin{array}{c}0.0 \\
4\end{array}$ & - & - & - & - & - & 0.27 & 0.72 & 1.66 & 2.02 & 4.43 \\
\hline CRP (mg/dL, <0.3) & & & $\begin{array}{l}32 . \\
54\end{array}$ & & & & $\begin{array}{l}19 . \\
87\end{array}$ & & & & 2.89 & 1.82 \\
\hline
\end{tabular}

Table 1: Serial TWBC/neutrophil count/CRP over the course of hospitalization.

of treatment before the development of agranulocytosis is 23 days (in our case, 20 days). As with previous reported cases, the neutrophil count recovered rapidly after the cloxacillin was stopped. A granulocyte colony stimulating factor was not needed.

The pathogenesis is poorly understood, though two mechanisms were proposed: direct toxic effect of the drug, and immunological allergic reaction and creation of neutrophil antibodies [3]. The presence of eosinophilia may suggest the second option, but it is not found in our case.

This case demonstrated a rather commonly used antibiotic can cause a potentially fatal result in treating patients with severe Staphylococcal infection, and it is important to monitor such patients during treatment, with a high index of suspicion should WBC is in decreasing trend towards neutropenia.

\section{Acknowledgement}

Director General, Ministry of Health, Malaysia for the approval to publish this case report.

\section{References}

1. Apinantriyo B, Lekhakula A, Rujirojindakul P (2011) Incidence, etiology and bone marrow characteristics of non-chemotherapy-induced agranulocytosis. Hematology 16: 50-53.

2. Leung WK, Chan TYK, Critchley JAJH (1995) Agranulocytosis in a drug addict with recurrent Staphylococcus aureus septicaemia. Postgrad Med J 71: 757758.

3. Tanous O, Hayek T, Hamoud S (2013) Transient Cloxacillin Induced Agranulocytosis with Eosinophilia and Elevated IgE Levels. Gen Med (Los Angel) 1: 111 